\title{
KONCEPCJA NOWEGO PODEJŚCIA BANKU DO FINANSOWANIA PRZEDSIĘWZIĘĆ REALIZOWANYCH W RAMACH PARTNERSTWA PUBLICZNO-PRYWATNEGO
}

\section{Wprowadzenie}

Uczestnicy partnerstwa publiczno-prywatnego (PPP) powinni wykazywać specjalne podejście do realizacji usług publicznych. Dotyczy to także podmiotów zaangażowanych $\mathrm{w}$ finansowanie. Potrzeba taka została dostrzeżona przez Komisję Europejską i wynika ze sformułowanych przez nią wielu wytycznych w zakresie podejmowania realizacji usług publicznych $\mathrm{w}$ ramach $\mathrm{PPP}^{1}$. Nie tylko ogrom podstawowych kwestii związanych z wyborem partnerstwa publiczno-prywatnego jako metody realizacji usług publicznych wskazuje na złożoność i specyfikę przedsięwzięcia PPP. Do uwzględnienia jest też gama różnych modeli $\mathrm{PPP}^{2}$, różne środowiska prawne (krajowe, regionalne regulacje prawne) dla realizacji usług publicznych, różne metody finansowania przedsięwzięć inwestycyjnych występujące na różnym stopniu rozwoju w danym kraju ${ }^{3}$, możliwe różne traktowanie PPP przez podmioty publiczne (jako metodę modernizacji państwa/reformy administracyjnej ${ }^{4}$, metodę

* Uniwersytet Ekonomiczny we Wrocławiu, Wydział Nauk Ekonomicznych.

1 Komisja Europejska, Wytyczne dotyczace udanego partnerstwa publiczno-prywatnego, Dyrektoriat Generalny, „Polityka Regionalna” 2003, s. 93-94, www.ppp.gov.pl/Poradnik_inwestora/AktyPrawne/Documents/Wytyczne_Komisji_PPP_190111.pdf

2 J. Zysnarski, Partnerstwo publiczno-prywatne. Wprowadzenie: geneza i modele PPP, www.komunalne. info/e4u.../1303_PPP_otwarcie_lublin_21-4-04.pdf

3 Przykłady Niemiec i Polski przedstawiono w: Partnerstwo Publiczno-Prywatne jako instrument do realizacji przedsięwzięć infrastrukturalnych $w$ obszarze przygranicznym Saksonii i Polski, red. H. Brezinski, D. Korenik, Verlag und Herstellung Graphische Werkstaetten Zittau GmbH, Freiberg-Wrocław 2014, s.159-206.

4 T. Mirow, Public Private Partnership-Eine notwendige Strategie zur Entlastung des Staates, w: Public Private Partnership. Neue Formen der öffentlichen Aufgabenerfuellung, red. D. Budaeus, P. Eichhorn, Nomos, Baden-Baden 1997, No. 41, s. 15-23. 
realizacji usługi publicznej ${ }^{5}$ lub metodę finansowania w warunkach ograniczonego budżetu publicznego ${ }^{6}$ ).

Mogłoby się wydawać, że ogrom różnych kwestii do rozpatrzenia dla zapewnienia udanego PPP, prawdziwych motywów jego inicjowania i możliwych struktur finansowych skłaniają banki do przyjęcia specjalnego, wysoce zindywidualizowanego podejścia do finansowania projektu PPP. Potrzebne są przy tym pewne ogólne ramy postępowania bankowego w procesie finansowania projektów PPP. Do wykorzystania mogą być dwie koncepcje postępowania, zależnie od konkretnej struktury realizacji przedsięwzięcia: analiza i ocena transakcji finansowania na zasadach project finance lub badanie zdolności kredytowej podmiotu ubiegającego się o finansowanie bankowe. Jednakże jest niebezpieczeństwo sprowadzenia postępowania do utartych schematów, właściwych dla myślenia w kategoriach stricte komercyjnych, tj. z pominięciem cech usług, które tradycyjnie realizowane są przez sektor publiczny (ekonomicznego uzasadnienia realizacji usługi przez sektor publiczny wynikającego z zawodności rynku: „niedoskonałości rynku” lub nieprawidłowości w funkcjonowaniu rynku ${ }^{7}$ ). Postępowanie banku, zubożone i wciśnięte w ramy utartych schematów analitycznych i oceniających, jest wprawdzie wygodne, bo bardziej ujednolicone i łatwe, ale też zredukowane do myślenia o PPP jako metodzie finansowania, a nie metodzie efektywnej realizacji usługi publicznej. W każdym rozumieniu PPP przez bank, silne będzie dążenie do zabezpieczenia własnego interesu w związku z finansowym zaangażowaniem się w projekt, ale różne mogą być sposoby i efekty zabezpieczania tego interesu. Celem niniejszego artykułu jest przede wszystkim prezentacja różnego podejścia banków do zagadnienia partnerstwa publiczno-prywatnego.

5 T. Winkelmann, Public Private Partnership: Auf der Suche nach Substanz. Eine Effiziensanalyse alternativer Beschaffungsformen auf kommunaler Ebene, Wyd.1, Nomos, Baden-Baden 2012, s. 27 i nast.; A. Cenkier, Partnerstwo Publiczno-Prywatne jako metoda wykonywania zadań publicznych, Oficyna Wydawnicza SGH, Warszawa 2009.

6 W. Bugajski, Partnerstwo Publiczno-Prywatne jako uzupelniajacy model finansowania, 2014, http:// samorzad.infor.pl/sektor/rozwoj_i_promocja/wspolpraca/artykuly/481587

7 H. Muehlenkamp, Marktversagen als oekonomische Begruendung fuer Interventionen der Öffentlichen Hand, w: Europeische Union und mitgliedsstaatliche Daseinsvorsorge, red. R. Hrbek, M. Nettesheim, Nomos, Baden-Baden 2002, No. 25. 


\section{Podejście banku do PPP wynikające z traktowania PPP jako metody finansowania zadania infrastrukturalnego}

Rozumiejąc PPP jako metodę finansowania, bank upatruje w wieloletnim, choć złożonym, przedsięwzięciu infrastrukturalnym okazję do osiągnięcia zysku przy akceptowalnym poziomie ryzyka. Gotowość banku do zaangażowania środków będzie wynikała z szacunków korzyści możliwych do otrzymania przy zadanych parametrach wnioskowanego projektu (w finansowaniu typu project finance) lub zdolności kredytowej podmiotu szukającego finansowania. Inwestycja zostanie poddana ocenie bankowej w taki sam sposób, jakby była przedsięwzięciem zupełnie komercyjnym - w ostatecznym rozstrzygnięciu założenia projektu będą musiały spełniać tzw. kryteria bankowalności projektów. Bankowalność oznacza spełnianie warunków stawianych przez stronę finansującą w projekcie. W opinii banku projekt zasługuje na finansowanie, jeśli spełnia kryteria efektywności, a tę ocenia się łącznie na podstawie wyników analizy prawnej, ekonomicznej/finansowej i technicznej wykonalności projektu.

W celu najlepszego zabezpieczenia własnego interesu bank może wyrazić zainteresowanie włączeniem go do uczestnictwa we wczesnej fazie projektu w charakterze wyspecjalizowanego doradcy, jednakże jest to kwestia zupełnie odrębna od bankowej oceny atrakcyjności partnerstwa publiczno-prywatnego jako takiego. Uczestnictwo banku we wczesnej fazie projektu ma wartość o tyle, że bank może przedstawić i wyjaśnić inicjującemu projekt (podmiotowi publicznemu) wymagania pod względem sposobów ograniczenia ryzyka bankowego oraz zasady swojego postępowania $\mathrm{w}$ trakcie trwania stosunku finansowania przedsięwzięcia (procedury postępowania, krytyczne momenty, w których bank zacznie reagować w celu ochrony swojego interesu). Bank może także lepiej poznać stan przygotowania inicjującego jego uczestnictwo w przedsięwzięciu oraz zaprezentować swój stosunek do zagrożeń i sposobów radzenia sobie z nimi na każdym etapie przedsięwzięcia - wszystko widziane w perspektywie ryzyka bankowego/ banku jako podmiotu chroniącego własny interes i opłacalności kosztowej (ograniczania kosztów administracyjnych w trakcie trwania umowy finansowania). Jest to oczywiście logiczne, ale może okazać się nie w pełni rozsądne wskutek pominięcia niektórych czynników ryzyka, tkwiących poza bankiem, które znalazłyby się w polu widzenia banku szerzej ujmującego PPP, tj. jako metodę najbardziej rentownej realizacji zadania publicznego. 


\section{Podejście banku do PPP wynikające z traktowania PPP jako najbardziej rentownej metody pozyskania usługi publicznej}

Przedstawione w tej części artykułu podejście stanowi efekt własnych przemyśleń i dociekań oraz dyskusji prowadzonych $\mathrm{w}$ trakcie kierowania pracami naukowo-badawczymi w zakresie potencjału i możliwości rzeczywistego wykorzystania PPP do realizacji projektów infrastrukturalnych w szczególności na obszarze przygranicznym Polski i Saksonii ${ }^{8}$.

W podejściu, w którym PPP jest traktowane jako metoda najbardziej rentownej realizacji zadania publicznego, powodzenie banku występującego w roli podmiotu finansującego projekt zależy od spełnienia następujących warunków:

1) ustalenia przez bank, czy porozumienie PPP może zostać dodane do listy opcji realizacji konkretnego zadania publicznego,

2) zachowania równości interesów w porozumieniu PPP,

3) w wypadku spełnienia obu powyższych warunków w fazie przedrealizacyjnej projektu niezbędne jest porównanie rentowności realizacji usługi publicznej różnymi metodami: tradycyjną (w systemie zamówień publicznych) i z wykorzystaniem PPP.

Ustalenie, czy porozumienie PPP może zostać dodane do listy opcji realizacji zadania publicznego wymaga głębszego zrozumienia przez wszystkich uczestników transakcji (ale przede wszystkim partnera publicznego i podmiotu finansującego) samej idei koncepcji PPP. Wychodzi się tu z założenia, że zastosowanie PPP jako metody pozyskiwania najbardziej rentownej realizacji usługi publicznej jest uzasadnione, jeżeli zostanie wykazane, że tego rodzaju porozumienia byłyby lepsze od tradycyjnych metod pozyskiwania usługi (system zamówień publicznych). Z perspektywy ekonomicznej potencjalne zalety i wady PPP wynikają ze specyficznych właściwości, które odróżniają PPP od tradycyjnych metod pozyskiwania. Te wyróżniające cechy koncentrują się na rodzaju konkurencji pomiędzy potencjalnymi partnerami prywatnymi PPP, tzw. podejściu opartym na cyklu życia, oraz podziale związanego z projektem ryzyka pomiędzy partnerów publicznych i prywatnych, a także specyficznych systemach zachęt. Wszystkie te cechy powinny zostać uwzględnione

\footnotetext{
8 Takie ustalenia uzyskano w ramach przeprowadzonego wspólnie przez Technische Universitaet Bergakademie Freiberg i Uniwersytet Ekonomiczny we Wrocławiu projektu naukowo-badawczego pt. Partnerstwo Publiczno-Prywatne jako instrument do realizacji przedsięwzięć infrastrukturalnych w obszarze granicznym Saksonii i Polski, PPPSAXPOL, współfinansowanego ze środków unijnych, zakończonego w 2014 r.
} 
także w postępowaniu bankowym, ukierunkowanym na poszukiwanie argumentów za podjęciem PPP jako najbardziej rentownej metody realizacji usługi publicznej.

Specyficzne właściwości usług publicznych są powodem, dla którego konkurencja pomiędzy ich dostawcami nie jest zwykle możliwa. Powołanie partnera prywatnego do realizacji usługi publicznej ma sens, jeśli pozwoli przezwyciężyć jednocześnie niedoskonałości rynku i często niższą efektywność sektora publicznego - czyli jeżeli zostanie zapewnione, że wybrany przedsiębiorca nie użyje uzyskanej poprzez PPP pozycji monopolisty do wykorzystania konsumentów ${ }^{9}$. Można to osiągnąć w sytuacji, gdy potencjalni partnerzy prywatni będą konkurować o prawo do ograniczonej czasowo obsługi rynku monopolistycznego (tzw. konkurencja o rynek) poprzez złożenie niejawnych ofert $\mathrm{w}$ postępowaniu przetargowym ${ }^{10}$.

Wykorzystanie projektów PPP powinno służyć do efektywniejszej niż w tradycyjny sposób realizacji usług infrastrukturalnych. Z doświadczeń innych krajów wynika, że często w wypadku projektów PPP efektywność całego procesu wykonania usługi (planowanie, budowa, eksploatacja, użytkowanie oraz finansowanie) jest wyższa niż w tradycyjnym pozyskiwaniu usługi infrastrukturalnej ${ }^{11}$. Zwykle projekty zorientowane są na większą efektywność kosztową, co powoduje lepszą produktywność wykonania usługi publicznej. Głównym źródłem wysokiego potencjału efektywności (value for money) jest $\mathrm{z}$ teoretycznego punktu widzenia łączenie różnych faz realizacji usługi infrastrukturalnej w pakiety, w połączeniu ze zorientowanym na wyniki opisem usługi. Łączenie faz realizacji usługi z perspektywy partnera prywatnego stanowi zachętę do optymalizacji kosztów w ciągu całego cyklu życia projektu (life cycle costing). W szczególności w polu widzenia trzeba mieć połączenie budowy i eksploatacji fizycznej infrastruktury. Teoretyczne uzasadnienie jest następujące: jeśli wynagrodzenie partnera prywatnego nie opiera się na wykonaniu fizycznej infrastruktury, lecz na przygotowaniu i długoterminowym udostępnieniu instalacji, to musi on uwzględnić koszty eksploatacji i utrzymania w swojej kalkulacji rentowności kosztowej ${ }^{12}$. Już podczas budowy infrastruktury dokonywane są inwestycje, które w przyszłości będą prowadziły do długoterminowych oszczędności kosztów eksploatacji i utrzymania infrastruktury lub optymalizacji kosztów całego projektu (budowy i eksploatacji). Kalkulacja uwzględniająca fazy realizacji

9 Zob. T. Vaelilae, How expensive are cost savings? On the economics of public-private partnerships, „EIB Papers" 2005, No. 10, s. 99.

${ }_{10}$ M. Fritsch, Marktversagen und Wirtschaftspolitik. Mikrooekonomische Analyse des vertraglichen Nachverhandlungsdesigns bei PPP-Projekten, Gabler Verlag, Wiesbaden 2011, s. 213.

11 A. Boardaman, A. Vining, Assessing the economic worth of public-partnerships, w: International Handbook on Public-Private Partnership, A. Graeme et. al., Cheltenham UK, Northhampton MA, s. 159-186.

12 J.E. Bettignies, T. Ross, The Economics of Public-Private Partnerships, "Canadian Public Policy/Analyse de Politiques" 2004, No. 30, s. 144. 
usługi nie występuje w wypadku tradycyjnej realizacji usługi, bowiem przedsiębiorca, któremu zlecono jedynie budowę fizycznej infrastruktury, nie odpowiada za koszty eksploatacji i stąd minimalizacja długookresowych kosztów eksploatacji nie leży w jego interesie ekonomicznym ${ }^{13}$. Natomiast strona publiczna jest zobligowana do optymalizacji kosztów w całym cyklu życia projektu przez odpowiednie zarządzanie procesem pozyskania infrastruktury.

Problematyczne w wypadku pakietowego przekazywania usług może być sporządzenie szczegółowej i kompletnej specyfikacji umownej usługi. Ze względu na kompleksowość i długoterminowość przedsięwzięć PPP, wyczerpujące opisanie wszystkich usług i ewentualności w porozumieniu służącym za podstawę współpracy nie jest możliwe. Istnieje niebezpieczeństwo, że partner prywatny wprawdzie obniży koszty wykonania usługi, jednak za cenę obniżenia jej jakości. Taka ewentualność stoi w sprzeczności z interesem partnera publicznego, który oczekuje dostosowania usługi do potrzeb jej użytkowników. Zalety łączenia usług w połączeniu z przekazaniem praw do kontroli nad infrastrukturą w ręce partnera prywatnego są więc silnie uzależnione od możliwości jak najdokładniejszej specyfikacji poszczególnych wymogów dotyczących usługi ${ }^{14}$. Znalazło to też potwierdzenie w rzeczywistości - doświadczenia zagraniczne, np. niemieckie, pokazały, że najbardziej ryzykowne okazywały się w szczególności niekompletne umowy pomiędzy publicznymi i prywatnymi partnerami oraz związany z nimi potencjalny brak elastyczności w wypadku koniecznej zmiany celów usługi, w połączeniu z niebezpieczeństwem możliwej utraty kontroli przez stronę publiczną ${ }^{15}$. Jednakże niekompletność umowy może się wiązać nie tylko z problematycznością jej zapewnienia, ale też obawą decydentów publicznych przed poniesieniem zbyt wysokich nakładów na zamierzenie PPP. Stąd potrzebne jest specjalistyczne doradztwo świadczone w formie zorganizowanej, a nie okazjonalnie (podmiot trudniący się doradztwem w zakresie PPP), umożliwiające zmniejszenie nakładów na przygotowanie zamierzenia PPP. Ponadto strona publiczna musi być w stanie monitorować realizację wymogów dotyczących usługi przez cały okres życia projektu i sankcjonować ewentualne niewłaściwe działania (kwestia systemu zachęt do szybkiej realizacji projektu).

W kwestii zachęt do szybkiej realizacji projektu istotne znaczenie ma często przywoływany argument za stosowaniem PPP, jakim jest tendencja projektów do dotrzymywania wyznaczonych terminów oraz restrykcji budżetowych w wyższym stopniu,

13 O. Hart, Incomplete Contracts and Public Ownership: Remarks, and an Application to Public-Private Partnerships, „Economic Journal” 2003, No. 113, s. C69-C76.

${ }^{14}$ O. Hart, op.cit.

15 B. Grabow, S. Schneider, PPP Projekte in Deutschland 2009. Erfahrungen, Verbreitung, Perspektiven, Deutsches Institut für Urbanistik (DIfU), Berlin 2009, s. 17-32. 
szczególnie podczas fazy budowy, w porównaniu do tradycyjnego pozyskiwania usługi ${ }^{16}$. Ta zależność wynika z przeniesienia odpowiedniego ryzyka na partnera prywatnego. Przeniesienie ryzyka budowalnego w połączeniu z ryzykiem finansowania oraz wynagrodzenie partnera prywatnego na podstawie ustalonej ceny, stymulują do terminowej realizacji budowy oraz dotrzymania dostępnego budżetu. Dodatkowo także tutaj znajdują zastosowanie potencjalne zalety łączenia fazy realizacji usługi. Jeśli partnerowi prywatnemu dodatkowo zostaną zlecone zadania związane z planowaniem, to będzie zainteresowany dążeniem do ograniczenia czasu budowy oraz niedopuszczenia do przekroczenia budżetu w rezultacie niewłaściwego planowania. Ale z drugiej strony może okazać się, że pakietowe przekazanie planowania i budowy przed zawarciem umowy prowadzi do powstania stosunkowo dużych kosztów umowy. Przyczyną jest tu wysoka złożoność zawieranych umów, a ponadto partner będzie chciał doliczyć do swojej oferty premię związaną z przeniesionym na niego ryzykiem $^{17}$. Dlatego trzeba przeanalizować, czy potencjalna oszczędność kosztów w fazie budowania zrównoważy wyższe koszty umowy oraz przeniesienia ryzyka.

Obok zalet szybkiej realizacji bieżącego projektu uwzględnić należy potencjalne zalety przeniesienia finansowania na partnera prywatnego. W szczególności gdy na przeszkodzie realizacji projektu stoją restrykcje budżetu publicznego, rozwiązanie PPP stanowi możliwość zainteresowania prywatnego kapitału inwestycyjnego, a tym samym krótkoterminowego obejścia ograniczeń budżetowych. Jeżeli jednak chęć obejścia ograniczeń budżetowych jest głównym lub jedynym motywem zainteresowania strony publicznej wykorzystaniem PPP (traktowanie PPP jako metody finansowania usługi publicznej), to z pola widzenia mogą zniknąć wszystkie ważne kwestie zapewnienia najbardziej rentownej realizacji usługi publicznej.

Bardziej właściwe jest traktowanie przeniesienia finansowania na partnera prywatnego nie tyle jako szczególnie korzystnego, co raczej ambiwalentnego dla strony publicznej rozwiązania. $Z$ jednej strony przekazanie finansowania powoduje zmianę strumienia płatności podmiotu publicznego, tzn. w wypadku tradycyjnego pozyskania usługi publicznej odpowiednie środki finansowe muszą zostać dostarczone przed rozpoczęciem budowy, a w PPP należy wypłacić partnerowi prywatnemu uzgodnione $\mathrm{w}$ umowie wynagrodzenie dopiero przy odbiorze infrastruktury lub po wykazaniu określonych postępów $\mathrm{w}$ budowie ${ }^{18}$, tak więc partner prywatny pokrywa wymagane zapotrzebowanie kapitału własnego lub obcego. Koszty pozyskania kapitału przez partnera prywatnego są jednak zwykle wyższe niż pozyskiwanego przez sektor

\footnotetext{
${ }^{16}$ C. Thomson, Private-public partnerships. Prerequisites for prime performance, „EIB Papers” 2005, No. 10, s. 118.

${ }^{17}$ C. Thomson, op.cit., s. 119.

18 T. Winkelmann, op.cit., s. 108.
} 
publiczny, a partner prywatny przeniesie wyższe koszty na partnera publicznego w ramach uzgodnionego wynagrodzenia (koszty finansowania są wyższe w porównaniu z zaciągnięciem kredytu przez podmiot publiczny). Jednakże i tu warto zauważyć, że ze względu na większą rentowność całego procesu dostarczenia usługi publicznej oraz wynikające z tego mniejsze koszty cyklu życia projektu, ogólne zapotrzebowanie na kapitał inwestycyjny może być niższe. W ostatecznym ujęciu należałoby zestawić ze sobą rzekomo wyższe koszty pozyskania kapitału z potencjalnymi oszczędnościami, aby ocenić korzyści ze stosowania PPP.

Wszystkie przedstawione kwestie prowadzące do sprawdzenia warunku pierwszego powinny być wzięte pod uwagę zarówno przez podmiot publiczny, jak i instytucję finansującą. Powodzenie projektu jest też uwarunkowane tym, czy zapewniono równość interesów poszczególnych stron projektu: publicznej, prywatnej i finansującej. Do nierównego traktowania interesów dochodzi w sytuacji, gdy wystąpi nieodpowiednie rozłożenie ryzyka pomiędzy stronami oraz błędy stron, w tym instytucji finansującej, w monitorowaniu przebiegu i ryzyka projektu.

Podział ryzyka związanego z przygotowaniem infrastruktury pomiędzy partnerów prywatnych i publicznych, dokonany zgodnie z zasadami prawidłowego podziału, stanowi zaletę PPP $\mathrm{w}$ stosunku do tradycyjnego pozyskania usługi publicznej ${ }^{19}$. Przeniesienie ryzyka na partnera prywatnego motywuje go do wykonania zadania zgodnie z umową, a dla partnera publicznego oznacza pozyskanie usługi lub pakietu usług praktycznie bez ryzyka (umożliwia to mechanizm odmowy wypłaty wynagrodzenia partnerowi prywatnemu w wypadku niewykonania usługi zgodnie z wymogami umownymi ${ }^{20}$. Podział ryzyka musi być jednak optymalny, tj. dokonany w taki sposób, by określone ryzyko (związane z planowaniem, budowlane, operacyjne, finansowe, własności/ryzyko związane z użytkowaniem ${ }^{21}$ ) ponosiła strona, która może najlepiej nim zarządzać lub kontrolować, a także ekonomicznie uzasadniony. Granicą ekonomicznej zasadności jest zrównanie się zaoszczędzonych przez podmiot publiczny kosztów ryzyka (przeniesionego na partnera prywatnego) z wynagrodzeniem dla partnera prywatnego, w którym zawarta jest premia za ryzyko. Teoretyczne uzasadnienie optymalnego podziału jest następujące: partner prywatny będzie dążył do unikania negatywnych efektów kosztowych związanych z niewłaściwym wykonaniem usługi, ale też za każde ryzyko, które ma zostać przeniesione, będzie wymagał premii

${ }^{19}$ G. Hodge, C. Greve, A. Boardman, International handbook on public private partnerships, Elgar, Cheltenham-Northampton 2010, s. 38.

${ }^{20}$ D. Grimsey, M. Lewis, Public private partnerships. The worldwide revolution in infrastructure provision and projecte finance, Elgar, Cheltenham, Northampton 2010, s. 106.

${ }^{21}$ Szerzej poszczególne rodzaje ryzyka odpowiednio do równych faz projektu przedstawia: G. Hodge, The risky business of public-private partnership, „Australian Journal of Public Administration” 2004, No. 4(63), s. 40 . 
w wysokości zależnej od jego zdolności do opanowania lub zarządzania określonym ryzykiem (częściowym); jeśli wynagrodzenie partnera prywatnego jest w większym stopniu uzależnione od ryzyka, którego nie może on kontrolować, to będzie podejmował wysiłki, by zabezpieczyć się przed potencjalnymi stratami z tytułu urzeczywistnionego ryzyka (np. poprzez polisę ubezpieczenia) - tym samym zwiększony nakład zostanie doliczony partnerowi publicznemu w postaci premii za ryzyko ${ }^{22}$. Z perspektywy podmiotu finansującego optymalny podział ryzyka stanowi najlepszą gwarancję utrzymania wydajnego i trwałego źródła spłaty udzielonego finansowania. Jednak oprócz tego ważne jest, by sama instytucja finansująca nie przyczyniła się do pogorszenia efektywności projektu w następstwie niedostatecznego monitoringu bankowego. Należy uwzględnić ewentualny negatywny wpływ przeświadczenia banku o zdolności partnera publicznego do sprawnego monitorowania projektu.

W zderzeniu z potrzebą banku dotyczącą obniżania kosztów administracyjnych może dojść do pogorszenia prowadzonego bankowego monitoringu projektu (zaniechania wykonywania niektórych czynności monitoringu). Struktura finansowania projektu oraz związane $\mathrm{z}$ nią zachowania instytucji finansującej stanowią istotny czynnik determinujący generowanie wzrostu efektywności projektu. Wynika to głównie z faktu, że rodzaj i struktura finansowania projektu PPP motywuje prywatnych partnerów do efektywnej realizacji usługi i tym samym wpływa na koszty cyklu życia całego projektu. Z jednej strony rodzi to potrzebę doboru odpowiedniej struktury finansowania, wspólnie $\mathrm{z}$ instytucją mającą go udzielić, a z drugiej strony dopilnowania wystarczającego poziomu monitorowania przebiegu projektu przez podmiot finansujący. Weźmy przypadek podstawowej struktury finansowania występującej za granicą (np. w Niemczech), jaką jest forfaiting ze zrzeczeniem się zarzutów przez partnera publicznego ${ }^{23}$. Ten rodzaj struktury finansowania jest właściwy dla PPP, w które wbudowany jest silny mechanizm zachęt w postaci motywacyjnych systemów wynagradzania partnera prywatnego. Przewidują one zwykle potrącenia przy płatnościach wynagrodzenia $\mathrm{w}$ razie nienależytej realizacji usługi przez partnera prywatnego. W modelu zrzeczenia się zarzutów, sprzeciwów i potrąceń przez zleceniodawcę publicznego, obniżenie wypłat wynagrodzeń jest możliwe tylko w ograniczonym zakresie (zleceniodawca publiczny dysponuje tylko ograniczonymi środkami nacisku, by narzucić zleceniobiorcy wykonanie umownych usług). Ponadto, ze względu na owo zrzeczenie się zarzutów przez partnera publicznego, ryzyko niewypłacalności zleceniobiorcy prywatnego jest de facto przenoszone z finansującego

22 M. Dewatripont, Public private partnerships: Contract design and risk transfer, „EIB Papers” 2005, No. 0257-7755, s. 121-122.

${ }_{23}$ Zob. L. Gramlich et al., Gabler Banklexikon: Bank-Boerse-Finanzierung, Springer Gabler, Wiesbaden 2012, s. 567. 
banku na zleceniodawcę publicznego. $Z$ doświadczeń zagranicznych wynika, że bywa, iż bank rezygnuje wówczas ze szczegółowej kontroli ekonomicznej i finansowej trwałości projektu w fazie koncepcyjnej, a także później - w fazie operacyjnej, a nawet może wymagać mniejszego wkładu własnego w strukturze finansowania ze względu na ryzyko projektu ocenione jako niskie (roszczenia banku zostaną zaspokojone w wyniku zrzeczenia się przez podmiot publiczny zarzutów) ${ }^{24}$. Tym samym monitoring bankowy może zostać osłabiony, skoro materialne konsekwencje świadczeń wykonywanych przez zleceniobiorcę dotyczą głównie zleceniodawcy publicznego.

Każde przerzucenie przez bank ryzyka w procesie monitorowania przedsięwzięcia na inną stronę projektu (zdanie się na profesjonalne umiejętności innej strony/partnera publicznego czy prywatnego), związane z poszukiwaniem oszczędności kosztowych monitorowania, oraz brak świadomości potencjalnego źródła ryzyka, wystawia bank na ryzyko pogorszenia rentowności PPP jako metody realizacji zadania publicznego (z konsekwencją negatywnego wpływu na wydajność źródła spłaty finansowania), zagraża prawidłowemu przebiegowi przedsięwzięcia i sprzyja przyjęciu asekuranckiej postawy banku (skłonność do wycofania lub zmniejszenia finansowania). Tym samym może dojść do sytuacji braku równości interesów stron transakcji, szczególnie jeśli bank zapewnił sobie silną pozycję w egzekwowaniu uprawnień, gdy tylko w opinii banku może dojść do urzeczywistnienia się ryzyka, przerzuconego na inną stronę, z którym ona sobie nie poradziła.

W podejściu zorientowanym na najbardziej rentowne wykonanie usługi publicznej, w przeciwieństwie do podejścia ograniczonego i zorientowanego na osiągnięcie wystarczającej (pod względem dochodu i bezpieczeństwa) korzyści własnej w transakcji finansowania projektu, potrzebne jest zbadanie, czy podmiot publiczny przeprowadził prawidłowo kalkulację rentowności usługi, która ma zostać pozyskana. Wynika to z założenia, że w interesie podmiotu finansującego, tak jak i w interesie podmiotu publicznego, leży finansowanie usługi publicznej pozyskiwanej przez zleceniodawcę metodą najbardziej rentowną i przy optymalnie rozłożonym ryzyku. Zasadne jest zachowanie sceptycyzmu przez bank rozważający wsparcie finansowe dla zamierzenia PPP. $Z$ doświadczeń zagranicznych, np. niemieckich, wynika, że dla wielu projektów PPP z przeszłości można było podważyć rzeczywiste korzyści PPP. Można by tu przytoczyć dokumenty Trybunałów Obrachunkowych federacji i krajów związkowych w Niemczech, np. Wspólna opinię w sprawie rentowności

\footnotetext{
${ }^{24}$ F. Eppinger, H. Kaesewieter, J. Mickisch, Die Bedeutung der Finanzierung innerhalb eines PPP-projektes, w: Public private partnership. Gestaltung von Leistungsbeschreibungen, Finanzierung, Ausschreibung und Vertraegen in der Praxis, red. B. Meyer-Hofman, F. Riemenschneider, O. Weihrauch, Carl Heymanss, KoelnMuenchen 2008, s. 367.
} 
projektów $P P P^{25}$, w której wskazano na błędy we wczesnych fazach koncepcji i planowania projektu, skutkujące mniejszymi faktycznymi korzyściami PPP (zarzutami są m.in.: dłuższe terminy budowy i planowania, wyższe koszty budowy, wyższe nakłady na renowację i remonty, wyższe koszty ryzyka) w porównaniu z konwencjonalnym pozyskiwaniem usługi publicznej. W wypadku porównań rentowności minionych projektów przyjmowano po części różne założenia dla projektów PPP oraz tradycyjnych metod pozyskiwania. Te często zbyt ogólne założenia prowadziły do niekorzystnego oszacowania kosztów konwencjonalnych wariantów pozyskiwania, które zdaniem Trybunałów Obrachunkowych jest często nieuzasadnione. Ponadto w przebadanych projektach w ramach porównania efektywności ekonomicznej konwencjonalne warianty pozyskiwania były obciążone szczególnie wysokimi kosztami ryzyka. Trybunały Obrachunkowe podkreślały, że przy pomocy podziału ryzyka możliwe jest ustalenie szacowanych kosztów konwencjonalnego nabycia w sposób celowo dyskryminujący metody tradycyjne. Wypływa $\mathrm{z}$ tego wniosek, że błędy pojawiające się już we wczesnej fazie planowania, przetargu oraz przygotowania umowy, stają się możliwymi głównymi przyczynami niespełnionych oczekiwań wobec wariantów PPP (w porównaniu $\mathrm{z}$ wariantami konwencjonalnego pozyskania usługi), w tym problemów z utrzymaniem finansowania obcego dla projektu. Stąd potrzebne jest obiektywne wsparcie doradcze, np. $z$ banku, dla wyboru najlepszego wariantu finansowania pozyskania usługi publicznej. Potrzeby tej nie umniejsza brak obligatoryjności dostarczenia dowodu na rentowność każdego rozwiązania finansowego pozyskiwania usługi publicznej, tak jak to ma miejsce w niemieckim prawie budżetowym na szczeblu federacji i krajów związkowych (żądanie potwierdzenia rentowności występowało początkowo w polskiej Ustawie o partnerstwie publiczno-prywatnym z 2005 r., z którego zrezygnowano na mocy nowelizacji Ustawy z $2008 \mathrm{r}^{26}$ ). Wręcz przeciwnie - rezygnacja ze wstępnego przeprowadzenia szczegółowego porównania rentowności może sprawić, że za pomocą PPP będą podejmowane projekty, które się do tego nie nadają (potencjał efektywności projektu nie zostanie zrealizowany).

Ostatecznie nasuwa się wniosek, że realizacja przez bank przedstawionego podejścia jest możliwa, jeżeli:

- bank będzie badał, czy potencjalnych zalet koncepcji PPP jako najbardziej efektywnej (rentownej) metody pozyskiwania usługi publicznej można dowieść indywidualnie, dla danego planowanego projektu oraz czy podmiot publiczny

${ }^{25}$ Gemeinsamer Erfahrungsbericht zur Wirtschaftlichkeit von OPP-Projekten, Rechnungshöfe des Bundes und der Länder, Wiesbaden 2011, s. 16-41.

26 T. Zacharewicz, The future of PPs in Poland: A Preliminary Assessment, w: Public Private Partnerships. Success and Failure Factors for In-Transition Countries, red. P. Urio, University Press of America, Lanham, Maryland 2010, s. 172-201. 
przeprowadził taką kalkulację ${ }^{27}$ samodzielnie lub przy wsparciu innego podmiotu (najlepiej podmiotu finansującego),

- bank oferuje doradztwo specjalistyczne, przede wszystkim w zakresie opracowania kompletnej umowy między partnerami projektu oraz możliwie najdokładniejszej specyfikacji wymogów usługi publicznej, i stanowi ono integralny element usługi finansowania projektu PPP (doradztwo nie jest opcjonalne, jak w wypadku podejścia tradycyjnego, powszechnego w bankowości komercyjnej),

- doradztwo jest zorientowane na zbudowanie i zachowanie równości interesów uczestników projektu, postrzegane przez bank jako najlepszy sposób zachowania bezpieczeństwa (ciągłości i utrzymania ryzyka na akceptowalnym poziomie) oraz rentowności przedsięwzięcia.

\section{Podsumowanie}

Z punktu widzenia zapewnienia bankowi bezpieczeństwa i powodzenia finansowania w całym okresie przedsięwzięcia nie jest wystarczające podejście tradycyjne do project finance oraz potrzeb kredytobiorcy. Zasadnicza różnica pomiędzy podejściem tradycyjnym a specjalnym dla PPP polega na innym postrzeganiu samej koncepcji PPP. W podejściu tradycyjnym PPP zostanie sprowadzone jedynie do wariantu (metody) finansowania projektów infrastrukturalnych/inwestycyjnych, z pominięciem niektórych ważnych aspektów, jakie zostałyby uwzględnione w traktowaniu PPP szerzej jako alternatywnej metody pozyskiwania publicznych usług infrastrukturalnych. Szersze traktowanie PPP jest dużo bardziej wymagające - na pierwszy plan wysuwa się ocena, czy dzięki specyficznym właściwościom koncepcji pozyskiwania usług publicznych poprzez PPP (uwzględnienie rodzaju konkurencji pomiędzy potencjalnymi partnerami prywatnymi, cyklu życia projektu, podziału ryzyka, systemu zachęt) możliwe jest doprowadzenie do długoterminowej optymalizacji (najbardziej rentownej i trwałej) realizacji usługi publicznej, co dla dostawcy finansowania oznacza wydajne i trwałe źródło spłaty długu. Zawężając PPP do metody finansowania, traci się z pola widzenia niektóre aspekty zapewnienia długoterminowej optymalizacji realizacji usługi publicznej (dbałość o zachowanie równego bezpieczeństwa interesów wszystkich podmiotów zaangażowanych w przedsięwzięcie,

27 Zob. H. Dedy, PPP ist kein Allheilmittel, w: PPP Projekte in Deutschland 2009. Erfahrungen, Verbreitung, Perspektiven, Deutsches Institut fuer Urbanistik (DIfU), Berlin 2009, s. 17; J. Hopfe, R. Ishorst, PPP trotz voller Kassen?, w: PPP Projekte in Deutschland 2009. Erfahrungen, Verbreitung, Perspektiven, Deutsches Institut fuer Urbanistik (DIfU), Berlin 2009, s. 160. 
a nie przede wszystkim lub tylko we własnym interesie banku), co może doprowadzić do iluzji trwałego i intratnego zaangażowania finansowego banku. W gruncie rzeczy oznacza to, że w innym od tradycyjnego podejścia do bankowego finansowania projektów PPP zmienia się rola banku, tylko z dostawcy finansowania (wierzyciela finansowego) na podmiot oceniający, czy i w jakich warunkach (w tym finansowych) PPP stanowi odpowiednie porozumienie kooperacyjne dla realizacji konkretnych zadań publicznych.

\section{Bibliografia}

Bettignies J.E., Ross T., The Economics of Public-Private Partnerships, "Canadian Public Policy/Analyse de Politiques" 2004, No. 30.

Boardaman A., Vining A., Assessing the economic worth of public-partnerships, w: International Handbook on Public-Private Partnership, A. Graeme et al., Cheltenham UK, Northhampton MA 2010.

Brigham E., Gapenski L., Zarzadzanie finansami, w: Zarzadzanie gminnymi inwestycjami infrastrukturalnymi, red. W. Kozłowski, Difin, Warszawa 2012.

Brzozowska K., Finansowanie inwestycji infrastrukturalnych przez kapitał prywatny na zasadzie project finance, CeDeWu, Warszawa 2009.

Bugajski W., Partnerstwo Publiczno-Prywatne jako uzupetniający model finansowania, 2014, http://samorzad.infor.pl/sektor/rozwoj_i_promocja/wspolpraca/artykuly/481587

Cenkier A., Partnerstwo Publiczno-Prywatne jako metoda wykonywania zadań publicznych, Oficyna Wydawnicza SGH, Warszawa 2009.

Dedy H., PPP ist kein Allheilmittel, w: PPP Projekte in Deutschland 2009. Erfahrungen, Verbreitung, Perspektiven, Deutsches Institut für Urbanistik (DIfU), Berlin 2009.

Dewatripont M., Public private partnerships: Contract design and risk transfer, „EIB Papers” 2005, No. 0257-7755.

Eppinger F., Kaesewieter H., Mickisch J., Die Bedeutung der Finanzierung innerhalb eines PPP-projektes, w: Public private partnership. Gestaltung von Leistungsbeschreibungen, Finanzierung, Ausschreibung und Verträgen in der Praxis, red. B. Meyer-Hofman, F. Riemenschneider, O. Weihrauch, C. Heymanss, Koeln-Muenchen 2008.

Fritsch M., Marktversagen und Wirtschaftspolitik. Mikrooekonomische Analyse des vertraglichen Nachverhandlungsdesigns bei PPP-Projekten, Gabler Verlag, Wiesbaden 2011.

Gemeinsamer Erfahrungsbericht zur Wirtschaftlichkeit von OPP-Projekten, Rechnungshöfe des Bundes und der Länder, Wiesbaden 2011.

Grabow B., Schneider S., PPP Projekte in Deutschland 2009. Erfahrungen, Verbreitung, Perspektiven, Deutsches Institut für Urbanistik (DIfU), Berlin 2009. 
Gramlich L. et al., Gabler Banklexikon: Bank-Börse-Finanzierung, Springer Gabler, Wiesbaden 2012.

Grimsey D., Lewis M., Public private partnerships. The worldwide revolution in infrastructure proviosion and projecte finance, Elgar, Cheltenham, Northampton MA 2010.

Hart O., Incomplete Contracts and Public Ownership: Remarks, and an Application to Public-Private Partnerships, “Economic Journal” 2003, No. 113.

Hodge G., The risky business of public-private partnerships, "Australian Journal of Public Administration" 2004, No. 4(63).

Hodge G., Greve C., Boardman A., International handbook on public private partnerships, Edward Elgar, Cheltenham, Northampton MA 2010.

Hopfe J., Ishorst R., PPP trotz voller Kassen?, w: PPP Projekte in Deutschland 2009. Erfahrungen, Verbreitung, Perspektiven, Deutsches Institut für Urbanistik (DIfU), Berlin 2009.

Komisja Europejska, Analiza kosztów i korzyści projektów inwestycyjnych. Przewodnik, Jednostka ds. ewaluacji, Dyrekcja Generalna - Polityka Regionalna, www.apsl.edu. pl/bfz/plili/Przewodnik_do_projektow_EFRR.pdf

Komisja Europejska, Wytyczne dotyczace udanego partnerstwa publiczno-prywatnego, Dyrektoriat Generalny, Polityka Regionalna 2003, www.ppp.gov.pl/Poradnik_inwestora/AktyPrawne/Documents/Wytyczne_Komisji_PPP_190111.pdf

Ministerstwo Rozwoju Regionalnego, Narodowe Strategiczne Ramy Odniesienia 2007-2013. Wytyczne $w$ zakresie wybranych zagadnień związanych z przygotowaniem projektów inwestycyjnych, w tym projektów generujących dochód, Warszawa 2007.

Mirow T., Public Private Partnership-Eine notwendige Strategie zur Entlastung des Staates, w: Public Private Partnership. Neue Formen der oeffentlichen Aufgabenerfuellung, red. D. Budaeus, P. Eichhorn, Nomos, Baden-Baden 1997, No. 41.

Muehlenkamp H., Marktversagen als ökonomische Begründung für Interventionen der Öffentlichen Hand, w: Europäische Union und mitgliedsstaatliche Daseinsvorsorge, red. R. Hrbek, M. Nettesheim, Nomos, Baden-Baden 2002, No. 25.

Partnerstwo Publiczno-Prywatne jako instrument do realizacji przedsięwzięć infrastrukturalnych w obszarze przygranicznym Saksonii i Polski, red. H. Brezinski, D. Korenik, Verlag und Herstellung Graphische Werkstätten Zittau GmbH, Freiberg-Wrocław 2014.

Thomson C., Private-public partnerships. Prerequisites for prime performance, „EIB Papers” 2005, No. 10.

Vaelilae T., How expensive are cost savings? On the economics of public-private partnerships, „EIB Papers” 2005, No. 10.

Winkelmann T., Public Private Partnership: Aufder Suche nach Substanz. Eine Effiziensanalyse alternativer Beschaffungsformen aufkommunaler Ebene, Nomos, Baden-Baden 2012.

Yescombe E., Public-private partnerships. Principles of policy and finance, Elsevier/BH, Amsterdam 2007. 
Zacharewicz T., The Future of PPPs in Poland: A Preliminary Assessment, w: Public Private Partnerships. Success and Failure Factors for In-Transition Countries, red. P. Urio, University Press of America, Lanham, Maryland 2010.

Zysnarski J., Partnerstwo publiczno-prywatne. Wprowadzenie: geneza i modele PPP, www. komunalne.info/e4u.../1303_PPP_otwarcie_lublin_21-4-04.pdf

\section{The Idea of New Approach to Financing Public-Private Partnership Projects by Banks}

The study focuses on public-private partnership (PPP) project from the point of view of a bank as a third party financing the PPP project. The aim of the study is to present two different approaches a bank can adopt: the one currently used by banks and an approach proposed by the author.

Keywords: public-private partnership project, financing by banks, concepts of financing

\section{L'idée de la nouvelle approche du financement des projets du partenariat public-privé par les banques}

L'étude se concentre sur le partenariat public-privé (PPP) du point de vue d'une banque comme un tiers du financement du projet du PPP. L'objectif de l'étude est de présenter deux approches différentes pour adopter par une banque: celle qui est actuellement utilisée par les banques et celle proposée par l'auteur.

Mots clés: le projet du partenariat public-privé, le financement par les banques, les concepts du financement

\section{Концепция нового подхода банков к финансированию проектов государственно-частного партнерства}

Предметом исследования являются проекты государственно-частного партнерства, (ГЧП) рассматриваемые со стороны банка как третьего лица, финансирующего проект ГЧП. Цель статьи состоит в представлении двух 
различных подходов, используемого в настоящее время банками и предложенного автором, к вопросу о предоставлении финансовой поддержки.

Ключевые слова: проекты государственно-частного партнерства, финансирование банками, концепции финансирования 